\title{
How Does Trust in Teams, Team Identification, and Organisational Identification Impact Trust in Organisations?
}

\author{
Catalina Diana Dumitru
}

Bremen International Graduate School of Social Sciences, Jacobs University, Germany

\author{
Margret Aenne Schoop \\ Bremen International Graduate School of Social Sciences, \\ Jacobs University, Germany
}

\begin{abstract}
:
Organisational and team identification are essential in explaining how trust emerges and develops among team members and within organisations (Ashforth and Mael, 1989). This study is particularly interested in examining the relationship between trust and identification at both team and organisational levels. Drawing from social identity theory, this research aims to identify the effect of trust on team identification and organisational identification. Our results indicate a positive relationship between the predictors and the outcome variable, highlighting the importance of trust to the functioning of teams and organisations.
\end{abstract}

Paper type: Research paper

Keywords: Trust in Organisations, Trust in Teams, Organisational Identification, Team Identification 


\section{Introduction}

The national and international business landscapes are becoming more and more competitive. For organisations to maintain the achieved competitive position and sustain it in a long run certain internal optimisation centred efforts are needed. One of the factors affecting organisational performance and individual productivity is trust (Aryee et al., 2002; Baer et al., 2015; Fulmer and Gelfand, 2012; Mayer et al., 1995; Schaubroeck et al., 2013).

The strategic implications of trust to team and organisational performance are welldocumented (Aryee et al., 2002; Costa et al., 2001; Dirks and Ferrin, 2002; Heffernan et al., 2008; Schaubroeck et al., 2013). Studies have found trust impacts at organisational and team levels, such as financial performance (Heffernan et al., 2008), organisational productivity (Aryee et al., 2002), teamwork (Costa et al., 2001), as well as leadership effectiveness (Dirks and Ferrin, 2002). More recently, scholars have found trust impacts at more micro level, such as self-efficacy (Baer et al., 2015) and job performance (Schaubroeck et al., 2013). The organisational trust literature has highlighted the importance of trust as source of relational and emotional support for newcomers (Schaubroeck et al., 2013), virtual teams (Jarvenpaa and Leidner, 1998; Prichard and Ashleigh, 2007), and emotional labours (Baer et al., 2015; Heffernan et al., 2008).

Both the complexity of business relationships and the increased uncertainty of the business environment cannot be handled without trust, making it "a highly desired property" (Lewicki and Bunker, 1996). However, this dynamic climate of development and competition has made it more difficult to develop and maintain trust within an organisation, as well as making it very risky to invest in trust. The effects of uncertainty and risk are more enhanced in times of re-organisation, change, merger and acquisition and it is precisely in these conditions that organisational trust appears to be the most significant. The nature of trust in these contexts seems to be both more necessary and more problematic.

Currall and Inkpen (2002) noted that organisational trust has been studied at a single level of analysis. Encouraged by a more recent review of trust research published by Fulmer and Gelfand (2012), we too share the view of analyzing how trust in the organisation may be affected by trust in other referents, in this case the team and organisational and team identification. Understanding how one referent might influence the other is particularly important for strategic human resource development programs in organisations (e.g. team interventions, team trainings), where it would be interesting to find out what elements it should address and the effects it has on each referent and on each level of analysis.

Thus, the research questions that we are interested in are: (1) what is the nature of the relationship between organisational trust and organisational identification; (2) how do trust in teams and identification with the team impact on this relationship, when controlling for several individual factors such as team size and team type.

International Journal of Management and Applied Research, 2016, Vol. 3, No. 2 
This article is structured as follows. Firstly, we review the most important theories explaining organisational trust and trust in teams. Secondly, we look at how the mechanisms of social identification play an important role into the functioning and development of trust within organisations, while discussing and pointing out what still remains unclear and how this research will fill the gap. We then describe our research design and how we went about collecting our data and testing the three main hypotheses. In the findings section, we present our main results highlighting the statistical analysis. Lastly, we discuss the implications and impact this research has both on a theoretical and practical level.

\section{Theoretical background}

The notion of trust is deeply rooted in organisation studies (Aryee et al., 2002; Cummings and Bromiley, 1996; Kozlowski and Bell, 2003; Kramer and Cook, 2004; Walumbwa et al., 2011) and psychological literature (Cook and Wall, 1980; Costa and Anderson, 2011; Dirks and Ferrin, 2002; Podsakoff et al., 2003). In this paper, we focus on the role of trust plays in team and organisational identification as well as the development of psychological bonds between team members and their organisation. According to Mayer et al. (1995) and Rousseau et al. (1998), there are two dimensions of trust: first, positive expectations of trustworthiness which refers to the perception towards trustees; and second, the willingness to accept vulnerability which refers to suspension of uncertainty or "leap of faith" (Möllering 2006: 109). Mayer et al. (1995) see willingness to accept vulnerability as an outcome of positive expectation. An individual is willing to trust someone is based on an assessment of that person's trustworthiness and thus, expecting that person will behave accordingly. For example, a supervisor has delegated an important task to his subordinate because he is "willing to accept vulnerability by engaging in risk taking" (Baer et al., 2015: 1640).

Scholars recognised the importance of trust for newcomers in gaining social acceptance and organisational identification (Schaubroeck et al., 2013). Individuals who work in high organisational identity are particularly concerned with behaving in a trustworthy manner and they are sensitive to others' behaviour. To be part of a team or to be a valuable member of an organisation, newcomers must first establish a reputation for trustworthiness before given meaningful tasks to contribute (Schaubroeck et al., 2013). McEvily et al. (2006) found that the trust is construed through the lens of shared group identity. This view is supported by Cummings and Bromiley (1996: 303) who define trust as "a common belief among a group of individuals that another group or individual (a) makes good-faith efforts to behave in accordance with any commitments both explicit or implicit, (b) is honest in whatever negotiations preceded such commitments, and (c) does not take excessive advantage of another even when the opportunity is available".

Teams are vital for organisational functioning (Kozlowski and Bell (2003; Zand, 1972). In this study, team refers to two or more individuals that are interdependent in performing their tasks, share responsibility for outcomes, accept vulnerability of others, and manage their relationships across organisational boundaries (Cohen and Bailey, 1997). Scholars maintained the importance of placing trust in employees as a signal to them that are valued and appreciated because feeling trusted by other team

International Journal of Management and Applied Research, 2016, Vol. 3, No. 2 
members or supervisor reflects the perception of given additional responsibilities (Baer et al., 2015), which is a key element of employee empowerment and job satisfaction (Han and Harms, 2010).

Lewicki and Bunker (1996) described three main phases in developing and maintaining trust relationships: calculus-based trust, knowledge-based trust and identification-based trust. Relevant to explain the relationship between trust development and identification is the third phase that develops over repeated interactions, as the relationship progresses. At the third stage, that of identificationbased trust, trust rests on a high level of empathy between team members. After establishing consistency and predictability of each other's behavior, team members access a new level of interaction where they know, understand and connect emotionally with each other in terms of values and emotions. This form of trust enables a correspondence of knowledge and "thus permits one to act as an agent for the other and substitute for the other in interpersonal transactions" (1996:119). The authors mention four types of activities that strengthen identification-based trust namely developing a collective identity (e.g. a team motto, a shared vision); being located in the same building or area; creating joint products or goals (e.g. project objectives, new product) and committing to commonly shared values (Lewicki and Bunker, 1996). By fostering these, a collective identity and being able to influence and individual's level of identification with the team it might be possible to develop identification-based trust.

Social identity theory postulates that people tend to use social classification and identification as a means of evaluating information in social environment and also locating themselves in such environment (Brewer and Gardner, 1996; Tajfel and Turner, 1979; Walumbwa et al. 2011). In line with self-categorisation theory, social identity theory argues that people who are motivated by their belongingness needs tend to categorise others and themselves into ingroups and outgroups (Ashforth and Mael, 1989). Naturally, such categorisation creates tension and conflict between and among group members who do not fit in. Han and Harms (2010) found that trust in peers mediates the relationship between conflicts and team identification. In particular, when a team member trust his team, he is more likely to avoid conflict because the success of team is greater than his own personal interest or issue with other team members. As Kramer (1996: 26) states: "trust in a collective entity has a basis in group identification", highlighting the role of trust in team formation and creating shared team identification. Thus, we predict that trust in peers influence team identification.

\section{H1: Trust in peers has a positive effect on team identification}

Organisational identification is an application of social identity theory in organisational settings (Schaubroeck et al., 2013). Research has shown that organisational identification is positively related with a number of workplace outcomes such as group performance (De Jong and Elfring, 2010) and productivity (Costa et al., 2001). According to Schaubroeck et al. (2013: 1149), "Organisational identification is the extent to which an individual defines himself or herself in terms of membership in the organization for which he or she works". Such emotional attachment is likely to influence an individual to exert efforts and perform in a role-appropriate manner.

International Journal of Management and Applied Research, 2016, Vol. 3, No. 2 
How does trust in teams, team identification, and organisational identification impact trust in organisations?

Therefore, in the lens of social identity theory, it is hypothesised here that there is a significant relationship between trust and organisational identification.

\section{H2: Trust in peers has a positive effect on organisational identification}

Drawing on social identity theory, we develop a model that portrays the relationship between trust, team, and organisational identification (see Figure 1). Exploring the relationship between trust and organisational identification is important, given that placing trusts in employees can satisfy belongingness need and sense of belonging can trigger a greater level of trust. It is argued here that trust may diffuse within an organisation over a long period of time, especially where the business leaders and team members carefully maintain trust-based relationship within and among groups and organisations (Currall and Inkpen, 2002). This leads to our third hypothesis:

H3: Team and organisational identification have a positive effect on organisational trust

Figure 1: Conceptual Model of Construct Relationships

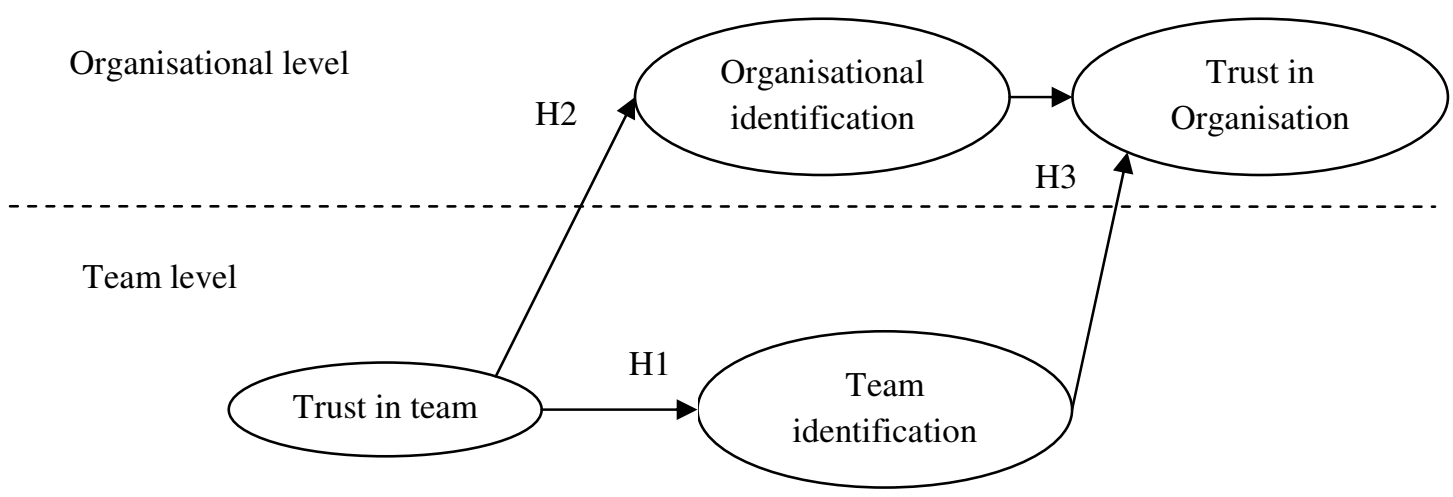

\section{Methodology}

\subsection{Sampling and data collection}

We recruited research participants from a private university in Germany. The sample was made of undergraduate students $(\mathrm{N}=222)$ who were recruited through convenience sampling. At the beginning of winter semester (September 2014), the students were informed about the study via emails, Facebook groups, as well as posters and flyers that were displayed throughout the campus. Research participants were incentivised with course credit and eligibility for entering a raffle to win Amazon vouchers. Interested students took part in an online survey designed to explore elements relating to development of trust. The survey took approximately 30 minutes to complete. In total, 222 respondents completed the online survey, providing an overall response rate of 58.07 percent, with 148 of them fully completed the surveys. The respondents surveyed ranged in age from 16-25 years. There were a higher proportion of females (52.3 per cent) than males (47.7 per cent).

International Journal of Management and Applied Research, 2016, Vol. 3, No. 2 


\subsection{Data analysis}

Firstly, the data collected from the online survey was transferred to SPSS. Following to that, the data went through a preliminary data processing by excluding incomplete questionnaire due to participant drop-outs. Next, the distribution of the scores was analysed to check if it fits the requirements for applying the specific statistics test, for examples: skewness, kurtosis, outliers. As part of the preliminary data analysis, the reliability coefficient was calculated for each scale. All constructs were measured using reliable multi-item scales drawing from the management literature and organisation studies. Finally, a multiple regression analysis and confirmatory factor analysis (CFA) for each of the four variables was performed and the scores for each variable were aggregated per individual case.

\subsection{Measures}

Following the study of and Han and Harms (2010), we used the four highest loading items of affective commitment scale to assess team identification. Sample items are 'I feel emotionally attached to my team/ university', 'I feel a strong sense of belonging to the team/ university', 'I feel the team's/ university's problems are my own' and 'I feel like part of the family in this team/at the university'. Items were rated on a seven-point scale anchored by $1=$ strongly disagree and $7=$ strongly agree. In this study, Cronbach's alpha for organisational identification was 0.85 and 0.78 for team identification.

We used five items adapted from De Jong and Elfring (2010) to measure trust in peers, which include: 'I can count on my team members', 'My team members will take my interests into account', 'I trust my team members', 'My team members will keep me informed', and 'My team colleagues will keep their word'. Items were rated on a seven-point scale anchored by $1=$ strongly disagree and $7=$ strongly agree. Cronbach's alpha for this study was 0.87 .

We used Tyler's (2003) eight-item scale to measure organisational trust. A sample item for measuring perceptions of the trustworthiness of the organisation is: 'My views are considered when decisions are made' while a sample item for measuring integrity is 'At the university, I am usually given an honest explanation for decisions'. As with previous measures, Items were rated on a seven-point scale anchored by $1=$ strongly disagree and $7=$ strongly agree. The alpha reliability of this scale was 0.83 .

\section{3. Findings}

A confirmatory factor analysis (CFA) of the four key variables (team identification, trust in team, organisational identification, and trust in organisation) was conducted to test their validity. The outcomes of the confirmatory factor analysis show that there is a statistically significant loading (ranging from .30 to $.77, \mathrm{p}<.05$ ) on the corresponding outcome variable. The CFA confirmed that the measurement model fits well with the data $(\mathrm{CFI}=0.96, \mathrm{AGFI}=0.89$, RMSEA $=0.05)$.

The next step was to perform a multiple regression analysis in order to find out whether the independent variables or the predictors have significant effects on the

International Journal of Management and Applied Research, 2016, Vol. 3, No. 2 
outcome variable and what interactions there are between these variables. The multiple regression analysis of the outcome variable on the predictors was performed. As shown in Table 1, the regression analysis was done stepwise and what we have identified is that the most significant predictor variable for organisational trust was organisational identification $\left(\mathrm{r}^{2}=.54, \mathrm{p}<.05\right)$.

That is, to get the unique contribution to $r^{2}$, first regression analysis was that of the outcome variable (organisational trust) on all the predictor variables. Then the outcome variable was regressed four times on the other predictors in a stepwise way each time excluding one predictor. The difference between the $r^{2}$ values gave us the squared semi partial correlation. As the analysis was performed in a stepwise manner, we can see the strength with which each of the independent variables is able to predict organisational trust. In that order, organisational identification is the most powerful predictor, followed by team identification and team trust.

Table 1 Hierarchical multiple regression analysis of individuals' organisational trust

\begin{tabular}{clcc}
\hline $\begin{array}{c}\text { Hierarchical } \\
\text { step }\end{array}$ & \multicolumn{1}{c}{ Predictor variable } & Total R square & $\begin{array}{c}\text { Incremental R } \\
\text { square }\end{array}$ \\
\hline 1 & Organisational identification & $0.54^{*}$ & $0.12^{*}$ \\
2 & Team identification & $0.51^{*}$ & $0.07^{*}$ \\
3 & Team trust & $0.39 *$ & $0.03 *$ \\
\hline & & & $* \mathrm{p}<0.05$
\end{tabular}

\section{Discussion}

Whilst this study was exploratory in nature, there were some significant results that enhanced our understanding regarding the relationship between team trust and organisational identification as well as team identification. Results indicate that perception of organisational identification is the strongest predictor of organisational trust, followed by team identification and team trust. Results of the multiple-regression analysis provided confirmation for the research hypothesis.

Our results indicate that organisational identification as well as team trust and identification are associated and may, therefore, function as predictors for individuals' trust in the organisation. Organisational identification is likely to be a good predictor for individuals' perception of the trustworthiness of the organisation. This finding is consistent with the previous research which showed that trust in peers is correlated significantly with organisational identification (Cook and Wall, 1980).

One way to build trust in peers is to foster team-skills training and an organisation can accomplish this in ad hoc experimental team setting (Prichard and Ashleigh, 2007). Prichard and Ashleigh (2007) show that especially if team training is delivered before collaborative tasks in temporary/ virtual teams, then the level of trust is likely to be higher. In another study that focused on communication and trust in virtual teams, Jarvenpaa and Leidner (1998) found that delivering teams a trust-building training before actually starting the project work promoted the development of positive

International Journal of Management and Applied Research, 2016, Vol. 3, No. 2 
perceptions of trustworthiness between team members. Their results are in line with our research in terms of how trust within an organisation can be fostered by developing trust in the team, organisational and team identification.

Results suggest that trust in peers enhances team identification (H1). These findings also imply that employees are more likely to develop organisational identification $(\mathrm{H} 2)$, and are more likely to develop trust in the organisation (H3) when team identity and organisational identity are evident. Our results also make contribution to the trust literature by addressing limited evidence on the effects of trust perceptions on team identification.

\section{Conclusion}

This study highlights reinforced the significant role of trust in team formation and organisational identity. Firstly, this study found that the extent to which individuals identify with their organisation is a critical predictor of their perceptions of the trustworthiness of the organisation. This is consistent with the social identity theory which suggests that identification is associated with a number of positive work behaviours and attitudes (Ashforth and Mael, 1989; Friedlander, 1970). Secondly, when individuals identify with their team, they exert additional efforts in achieving team goals (Han and Harms 2010). In short, trust perception influences work attitude and behaviour. Thirdly, team identification is associated with their trust perception towards the organisation. This study also suggests that trust in organisation could be shaped by cultivating team members' sense of belongingness and team identification. It is therefore important for management to cultivate trust of their organisation members for greater performance and efficiency.

This study has several implications for business practitioners and human resource professionals. First, human resource managers should be aware of the notion of team identity and trust as well as how they can build and develop trust in peers. This is because an increase in trust could result in high involvement workplace (Baer et al., 2015) and effectiveness in organisations (Ashforth and Mael, 1989). Moreover, the human resource professionals should consider teambuilding exercises to cultivate trust and team identification. Organisational members, especially newcomers, should be better able to work as a team if they were given more opportunities to socialise and build trust.

This study has several limitations that should be noted. First, our sample size was approximately 200 respondents. Research with larger samples would provide stronger and more convincing evidence for the generalisability of our findings. The second limitation of this study is related to the representative of sample. In this study, the sample consisted of students from a private university in one country (Germany). The present findings can be extended by examining the nature of organisational trust in different cultural and organisational settings. Such studies could seek to explore the perception of organisational trust in different industries and countries, which may have varying degree of trust development in team and organisational levels. Future studies may also examine how perception towards organisational trust evolves over time and how individuals develop and gain trust in actual organisational settings.

International Journal of Management and Applied Research, 2016, Vol. 3, No. 2 
An additional limitation is its reliance on self-reported measures. The linkages between organisational identity, team trust, and team identification could have been subject to some inflation. Future studies could include multiple sources and data collection waves, allowing researchers to use temporal separation and source separation to mitigate common method bias (Podsakoff et al., 2003).

\section{Acknowledgements}

This study was supported by Deutsche Forschungsgesellschaft (German Research Foundation) and Bremen International Graduate School of Social Sciences, an interdisciplinary programme between Bremen University and Jacobs University.

\section{References}

1. Aryee, S., Budhwar, P. S., and Chen, Z. X. (2002), "Trust as a mediator of the relationship between organisational justice and work outcomes: test of a social exchange model", Journal of Organisational Behavior, Vol. 23, No. 3, pp. 267285. https://doi.org/10.1002/job.138

2. Ashforth, B. E., and Mael, F. (1989), "Social identity theory and the organisation", The Academy of Management Review, Vol. 14, No. 1, pp. 20-39. https://doi.org/10.2307/258189

3. Baer, M. D., Dhensa-Khahlion, R. K., Colquitt, J. A., Rodell, J. B., Outlaw, R. and Long, D. M. (2015), "Uneasy lies the head that bears the trust: the effects of feeling trusted on emotional exhaustion", Academy Of Management Journal, Vol. 58, No. 6, pp. 1637-1657. https://doi.org/10.5465/amj.2014.0246

4. Cohen, S. G., and Bailey, D. E. (1997), "What makes teams work: Group effectiveness research from the shop floor to the executive suite", Journal of Management, Vol. 23, No. 3, pp. 239-290. https://doi.org/10.1177/014920639702300303

5. Cook, J. and Wall, T. (1980), "New work attitude measures of trust, organizational commitment and personal need non-fulfillment", Journal of Occupational Psychology, Vol. 53, No. 1, pp. 39-52. https://doi.org/10.1111/j.20448325.1980.tb00005.x

6. Costa, A. C., and Anderson, N. (2011), "Measuring trust in teams: Development and validation of a multifaceted measure of formative and reflective indicators of team trust", European Journal of Work and Organisational Psychology, Vol. 20, No. 1, pp. 119-154. https://doi.org/10.1080/13594320903272083

7. Costa, A. C., Roe, R. A., and Taillieu, T. (2001), "Trust within teams: The relation with performance effectiveness", European Journal of Work and Organisational Psychology, Vol. 10, No. 3, pp. 225-244. https://doi.org/10.1080/13594320143000654

8. Cummings, L. L., and Bromiley, P. (1996), "The organisational trust inventory (OTI): Development and validation”, In: R. M. Kramer and T. R. Tyler (Eds.), Trust in organisations: Frontiers of Theory and Research, Sage Publications. pp. 302-331

International Journal of Management and Applied Research, 2016, Vol. 3, No. 2 
9. Currall, S. C., and Inkpen, A. C. (2002), "A multilevel approach to trust in joint ventures”, Journal of International Business Studies, Vol. 33, No. 3, pp. 479-495. https://doi.org/10.1057/palgrave.jibs.8491027

10. De Jong, B. A., and Elfring, T. (2010), "How does trust affect the performance of ongoing teams? The mediating role of reflexivity, monitoring, and effort", Academy of Management Journal, Vol. 53, No. 3, pp. 535-549. https://doi.org/10.5465/AMJ.2010.51468649

11. Dirks, K. T., and Ferrin, D. L. (2002), "Trust in leadership: Meta-analytic findings and implications for research and practice", Journal of Applied Psychology, Vol. 87, No. 4, pp. 611-628. https://doi.org/10.1037//0021-9010.87.4.611

12. Friedlander, F. (1970), "The primacy of trust as a facilitator of further group accomplishment", The Journal of Applied Behavioral Science, Vol. 6, No. 4, pp. 387-400. https://doi.org/10.1177/002188637000600401

13. Fulmer, C. A., and Gelfand, M. J. (2012), "At what level (and in whom) we trust: Trust across multiple organisational levels", Journal of Management, Vol. 38, No. 4, pp. 1167-1230. https://doi.org/10.1177/0149206312439327

14. Han, G. and Harms, P. D. (2010), "Team identification, trust and conflict: A mediation model", International Journal of Conflict Management, Vol. 21, No. 1, pp. 20-43. https://doi.org/10.1108/10444061011016614

15. Heffernan, T.; O'Neill, G.; Travaglione, T. and Droulers, M. (2008), "Relationship marketing: The impact of emotional intelligence and trust on bank performance", International Journal of Bank Marketing, Vol. 26, No. 3, pp.183 - 199. https://doi.org/10.1108/02652320810864652

16. Jarvenpaa, S. L., and Leidner, D. E. (1998), "Communication and trust in global virtual teams", Journal of Computer-Mediated Communication, Vol. 3, No. 4, pp. 0. https://doi.org/10.1111/j.1083-6101.1998.tb00080.x

17. Kozlowski, S. W. J., and Bell, B. S. (2003), "Work groups and teams in organisations", In: W. C. Borman, D. R. Ilgen, and R. J. Klimoski (Eds.), Handbook of psychology Vol. 12: Industrial and Organisational Psychology, New York: Wiley-Blackwell Publishing Ltd., pp. 333-375

18. Kramer, R. M., and Cook, K. S. (2004), Trust and distrust in organisations: Dilemmas and Approaches, New York: Russel Sage Foundation.

19. Lewicki, R. J., and Bunker, B. B. (1996), "Developing and maintaining trust in work relationships", In: R. M. Kramer and T. R. Tyler (Eds.), Trust in organisations: Frontiers of Theory and Research, Sage Publications. pp. 114-139

20. Mayer, R. C., Davis, J. H., and Schoorman, F. D. (1995), “An integrative model of organisational trust", The Academy of Management Review, Vol. 20, No. 3, pp. 709-734. https://doi.org/10.5465/AMR.1995.9508080335

21. McEvily, B., Webet, R. A., Bicchieri, C., and Ho, Y. T. (2006), "Can groups be trusted? An experimental study of trust in collective entities", In: R. Bachmann and A. Zaheer (Eds.), Handbook of Trust Research, Cheltenham: Edward Elgar Publishing.

International Journal of Management and Applied Research, 2016, Vol. 3, No. 2 
How does trust in teams, team identification, and organisational identification impact trust in organisations?

22. Möllering, G. (2006), Trust: Reason, routine, reflexivity. Oxford: Elsevier.

23. Podsakoff, P. M., MacKenzie, S. B., Lee, J.-Y. and Podsakoff, N. P. (2003), "Common method biases in behavioral research: A critical review of the literature and recommended remedies", Journal of Applied Psychology, Vol. 88, No. 5, pp. 879-903. https://doi.org/10.1037/0021-9010.88.5.879

24. Prichard, J. S., and Ashleigh, M. J. (2007), "The effects of team-skills training on transactive memory and performance”, Small Group Research, Vol. 38, No. 6, pp. 696-726. https://doi.org/10.1177/1046496407304923

25. Rousseau, D. M., Sitkin, S. B., Burt, R. S., and Camerer, C. (1998), "Not so different after all: A cross-discipline view of trust", Academy of Management Review, Vol. 23, No. 3, pp. 393-404. https://doi.org/10.5465/AMR.1998.926617

26. Schaubroeck, J. M.; Peng, A. C. and Hannah, S. T. (2013), "Developing Trust with Peers and Leaders: Impacts on Organisational Identification and Performance during Entry", Academy Of Management Journal, Vol. 56, No. 4, pp. 1148-1168. https://doi.org/10.5465/amj.2011.0358

27. Tyler, T. R. (2003) , “Trust within organisations”, Personnel Review, Vol. 32, No. 5, pp. 556-568. https://doi.org/10.1108/00483480310488333

28. Walumbwa, F. O., Luthans, F., Avey, J. B., and Oke, A. (2011), “Authentically leading groups: The mediating role of collective psychological capital and trust", Journal of Organisational Behavior, Vol. 32, No. 1, pp. 4-24. https://doi.org/10.1002/job.653

29. Zand, D. E. (1972), “Trust and managerial problem solving”, Administrative Science Quarterly, Vol. 17, No. 2, pp. 229-239. https://doi.org/10.2307/2393957

International Journal of Management and Applied Research, 2016, Vol. 3, No. 2 